Tomasz Cieślik

Instytut Fizyki Jądrowej PAN

Krzysztof Kogut

AGH Akademia Górniczo-Hutnicza, Wydział Energetyki i Paliw

\title{
Prognozowanie pracy sieci gazowej za pomocą sztucznych sieci neuronowych
}

\begin{abstract}
Podczas wprowadzania ograniczeń $\mathrm{w}$ dostawach gazu ziemnego przedsiębiorstwa przemysłowe odczuwają problemy z zaopatrzeniem w gaz, co przekłada się na ich sytuację finansową. W takim przypadku, zakładając rozwój liberalizacji na rynku gazu ziemnego, może nastąpić spadek cen paliw gazowych. Gospodarstwa domowe, które korzystają z gazu w celach komunalnych (ogrzewanie budynków) oraz bytowych (przygotowanie posiłków i ogrzewanie wody) z mocy prawa są chronione w razie zakłóceń dostaw gaz ziemnego. Wystąpienie zakłóceń (nieodpowiednia kaloryczność gazu) i braków dostaw gazu ziemnego może skłonić także wielu użytkowników z tej najliczniejszej grupy do rezygnacji z korzystania z paliw gazowych. Niniejszy artykuł przedstawia możliwości prognozowania pracy sieci gazowej średniego ciśnienia. Analizowanym parametrem jest spadek ciśnienia gazu dostarczanego do odbiorców domowych przyłączonych do systemu sieci dystrybucyjnej. Dzięki uzyskanym pomiarom przepływu gazu, temperatury oraz spadku ciśnienia możliwe będą analizy wykorzystujące wzory matematyczne, program STANET oraz uczenie z wykorzystaniem sztucznej sieci neuronowej. Otrzymane wyniki dają możliwość porównania poszczególnych metod w 20-godzinnym przewidywaniu zmian ciśnienia gazu.
\end{abstract}

Słowa kluczowe: sieć neuronowa, prognozowanie, sieć gazowa, spadek ciśnienia.

\section{Forecasting the work of gas network by means of artificial neural network}

During the introduction of restrictions in the supply of natural gas, industrial enterprises experience problems with the supply of gas, which is reflected in their financial situation. In this case, given the development of the liberalization of the natural gas market, there may be a decline in prices of gas. Households that use gas for utility purposes (heating of buildings) and living (preparing meals and heating water) by law are protected in the event of disruption in the supply of natural gas. Any disruptions such as the inadequate calorific value of gas and shortages of natural gas supplies may also induce many users from the largest group to abandon the use of gaseous fuels. The following article introduces possibilities concerning the forecast of how medium-pressure gas network, works. The parameter which is analyzed is the decrease in the gas pressure supplied to households connected to the distribution network system. The measurements (gas flow, temperature and the decrease in the pressure) will enable analysis using mathematical formulas, STANET software and the model of artificial neural network. The results will enable a comparison of particular methods in a twenty-hour forecasting of changes in gas pressure.

Key word: neural network, forecasting, gas network, pressure drop.

\section{Wprowadzenie}

Obecne gospodarki światowe opierają się na pięciu głównych źródłach energii. Są nimi węgiel, ropa naftowa, gaz ziemny i paliwo jądrowe oraz energia pochodząca ze źródeł odnawialnych (OZE). Udział tych źródeł w gospodarce danego kraju zależy m.in. od położenia geograficznego, stanu posiadania zasobów surowców energetycznych oraz rozwoju ekonomicznego.

Gaz ziemny jest dostarczany za pomocą sieci wysokiego ciśnienia do odbiorców przemysłowych (np. elektrowni, 
zakładów petrochemicznych), którzy wykorzystują go do realizowania swojej misji, dzięki czemu zapewniony zostaje stabilny wzrost gospodarki oraz rozwój przedsiębiorstw. Za pomocą sieci dystrybucyjnej średniego i niskiego ciśnienia gaz dostarczany jest do odbiorców komunalnych.

Prognozowanie pracy sieci gazowej oraz zużycia gazu w zależności od pory roku jest niezmiernie istotne w procesie eksploatacji. Dzięki prognozom można przewidzieć zwiększone lub zmniejszone zużycie gazu oraz spadki ciśnień w gazociągach. Informacje te pozwalają ułożyć plan remontów sieci i stacji gazowych tak, aby dostawy nie były zakłócane. Inną bardzo ważną zaletą prognozowania jest możliwość przewidzenia konsumpcji w zależności od zmiany temperatury oraz siły i kierunku wiatru. Pozwala to na prowadzenie racjonalnej polityki magazynowania gazu ziemnego.

\section{Sztuczne sieci neuronowe}

Rozwój sztucznych sieci neuronowych nastąpił dopiero w połowie XX wieku, kiedy to rozpoczęto badania nad komórkami ośrodkowymi zwierząt i człowieka. W 1957 roku zostaje opracowany przez Rosenblatta pierwszy działający perceptor. Jednak najważniejszym okazał się 1986 rok, gdy publikacja Rumelharta i McClellanda podsumowała dotychczasowy stan badań nad sztucznymi sieciami neuronowymi oraz przedstawiła algorytm uczenia sieci wielowarstwowych o nieliniowych neuronach. Lata 90. ubiegłego wieku przyniosły dynamiczny rozwój zastosowania sieci neuronowych w medycynie, przemyśle oraz edukacji $[13,16,17,19]$.

\section{Wykorzystanie sztucznych sieci neuronowych w gazownictwie}

Sieci neuronowych w gazownictwie używa się między innymi podczas prowadzenia prac wiertniczych, analizy skał i doboru technologii wiercenia, oceny parametrów złóż czy prognozowania zużycia gazu. Firma Halliburton stosuje sieci w trakcie odwiertów przy poszukiwaniu ropy naftowej, a firma General Dynamic opracowała system klasyfikujący i rozpoznający do poszukiwania złóż gazu i ropy na morzu. Ciągle rozwijana jest technika prognozowania spadków ciśnień za pomocą sieci neuronowych [2, 3, 8-10, $13,14,16-19]$.

\section{Korzyści wynikające z prognozowania poboru gazu}

Prognozowanie poboru gazu dostarcza korzyści pozwalających na $[2,3,9,10,14,16]$ :

- modelowanie zagrożeń wynikających z jego dostaw,

- wykorzystanie w sposób optymalny infrastruktury,

- uzyskanie cennych informacji dotyczących magazynowania gazu,

- dostarczenie informacji o poborach dla modeli symulacyjnych, dzięki czemu można prognozować - informacje te pozwalają na przewidzenie zapotrzebowania np. na energię elektryczną, a co za tym idzie - na surowce,

- prognozowanie poboru gazu w punktach bez systemu teleinformatycznego.

\section{Biologiczne podstawy sztucznej sieci neuronowej}

Model sztucznego neuronu został opracowany na podstawie neuronu biologicznego (rysunek 1), który wchodzi w skład układu nerwowego organizmów żywych.

Opis funkcji poszczególnych elementów [13, 16, 17, 19]:

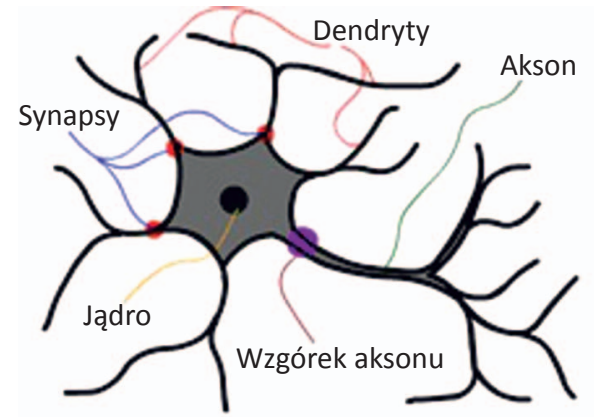

Rys. 1. Model biologiczny komórki neuronowej [4]

- jądro - miejsce przetwarzania sygnałów doprowadzonych do neuronu,

- akson - wyprowadza sygnał wyjściowy i przekazuje go do kolejnych neuronów (odbiorników informacji),

- wzgórek aksonu - wysyła sygnał, który przebiega następnie przez akson,

- dendryty - zbierają sygnały z różnych komórek i receptorów i doprowadzają je do jądra komórki,

- $\quad$ synapsa - przekazuje sygnał z waga - punkt połączenia pomiędzy neuronami.

\section{Budowa i zasada działania sztucznego neuronu}

Sztuczny neuron (rysunek 2) jest podstawowym elementem tworzącym sztuczną sieć neuronową. Można rozpatrywać go jako specyficzny przetwornik sygnałów działających według następujących zasad. Na wejściu do przetwornika zadawane są sygnały nazywane sygnałami wejściowymi, które następnie są mnożone przez odpowiednie współczynniki wag. „Ważone” sygnały wejściowe są następnie sumowane i korygowane o stałą wartość progową. Na tej podstawie wyznacza się pobudzenie neuronu. Wzbudzone sygnały przechodzą przez nieliniową funkcję aktywacji, dając na wyj- 
ściu sieci odpowiedni sygnał [20].

Sztuczne neurony (rysunek 2) można porównać do ich

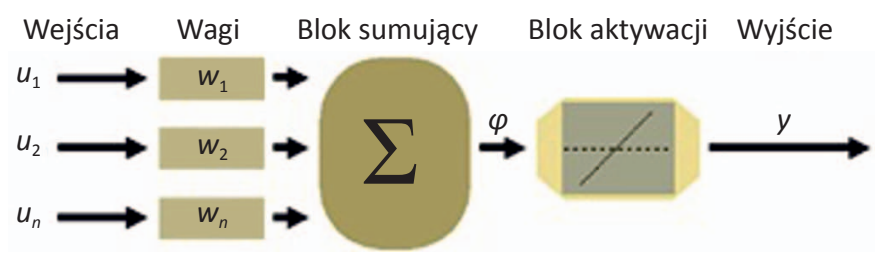

Rys. 2. Model sztucznego neuronu [15]

biologicznych odpowiedników:

$u_{i}$ - wejścia - to dendryty, lub ściślej - sygnały przez nie dochodzące,

$w_{i}$ - wagi - są odpowiednikami synaps,

$\Sigma$ - blok sumacyjny - odpowiednik jądra,

$f()$ - blok aktywacji - to odpowiednik wzgórka aksonu,

$y$ - wyjście - to odpowiednik aksonu.

\section{Budowa i zasada działania sztucznej sieci neuronowej}

Obecnie wykorzystywane są sieci warstwowe:

- warstwa zewnętrzna przyjmuje sygnały,

- warstwa ukryta przetwarza sygnały,

- warstwa wyjściowa generuje sygnały.

Wejściowe sygnały skierowane są do neuronów zewnętrznych, które nie przetwarzają ich, ale przesyłają dalej do neuronów warstwy ukrytej.

Następny etap to aktywizacja neuronów w warstwie ukrytej. Neurony te wykorzystują swoje wagi; najpierw modyfikują sygnał wejściowy, a następnie, korzystając ze swoich charakterystyk, wyliczają wartość sygnału wyjściowego. Kiedy zakończy się przetwarzanie sygnałów przez sztuczne neurony należące do warstwy ukrytej, powstają sygnały pośrednie kierowane do warstwy wyjściowej. Neurony należące do warstwy wyjściowej stosują swoje umiejętności w agregacji (łączeniu) sygnałów oraz swoje charakterystyki w celu uzy- skania końcowych rozwiązań na wyjściu [13, 16, 17, 19].

\section{Uczenie sieci neuronowej}

Sieci neuronowe wykazują zdolności adaptacyjne. Uczenie polega na adaptacyjnym, automatycznym dobraniu takich wartości wag, przy których sieć będzie możliwie najlepiej rozwiązywać zadanie w warunkach środowiskowych, określanych odpowiednimi wymaganiami co do przetworzenia danych wejściowych w wyjściowe. Okres uczenia (trenowania) sztucznej sieci neuronowej poprzedzony jest gromadzeniem danych, które umożliwią jej określenie sposobu (drogi) znalezienia rozwiązania danego problemu $[5,7,11$, $13,16,17,19]$.

\section{Uczenie nadzorowane}

Dane są zestawy prób uczących, które składają się z par wejście-wyjście $\left(x_{j}, z_{j}\right)$, gdzie $z_{j}$ jest pożądaną odpowiedzią sieci na sygnały wejściowe $x_{j}(j=1 \ldots n)$. Zadaniem sztucznej sieci neuronowej jest nauczyć się jak najlepiej funkcji przybliżającej powiązanie wejścia z wyjściem $[11,13]$.

\section{Uczenie bez nadzoru}

Obok przywołanego wyżej schematu uczenia z nauczycielem występuje też szereg metod tak zwanego uczenia bez nauczyciela. Jedna $\mathrm{z}$ nich polega na tym, że na wejście sieci podajemy wyłącznie szeregi przykładowych danych $\left(x_{j}\right)$ wejściowych, bez podawania informacji związanej z oczekiwanym sygnałem wyjściowym. Brak jest wiadomości na temat odległości $y$ (obliczonej wartości) od $z$ (oczekiwanej). Adekwatnie do danego problemu stworzona sieć neuronowa jest w stanie wykorzystać same tylko obserwacje wejściowych sygnałów i zbudować na ich podstawie algorytm swojego działania - najczęściej polegający na automatycznym wykrywaniu klasy powtarzających się sygnałów wejściowych i uczeniu się rozpoznawania typowych wzorców sygnałów $[11,13]$.

\section{Opis badanej sieci gazowej}

W niniejszej pracy do obliczeń zostały wykorzystane pomiary z odcinka gazociągu o długości $1825 \mathrm{~m}$ i średnicy wewnętrznej $150 \mathrm{~mm}$. W trakcie pomiarów zbierano wartości: strumienia przepływającego gazu, temperatury oraz ciśnienia na początku i na końcu odcinka.

\section{Równania dla ciśnień średnich}

Do obliczeń spadku ciśnienia w gazociągu zostały zastosowane empiryczne równania Renouarda (1) i Biela-Lummerta (2). W tablicy 1 przedstawiono wartości liczby gazo- wej $Z$ wykorzystywanej w równaniu Biela-Lummerta, której wartość zależy od gęstości względnej gazu.

$$
\begin{aligned}
& p_{1}-p_{2}=2557,07 \cdot d \cdot L \cdot \frac{Q_{n}^{1,82}}{D_{w}^{4,82}} \\
& p_{1}-p_{2}=42,604 \cdot Z \cdot L \cdot \frac{Q_{n}^{1,875}}{D_{W}^{5}}
\end{aligned}
$$

gdzie:

$d$ - gęstość względna gazu,

$D_{w}$ - średnica wewnętrzna gazociągu $[\mathrm{mm}]$, 
Tablica 1. Wartości liczby gazowej $Z$ ze wzoru Biela-Lummerta

\begin{tabular}{|l|l|l|l|l|l|l|l|l|l|l|l|l|l|}
\hline $\boldsymbol{d}$ & 0,40 & 0,45 & 0,50 & 0,55 & 0,60 & 0,65 & 0,70 & 0,75 & 0,80 & 0,85 & 0,90 & 0,95 & 1,00 \\
\hline $\boldsymbol{Z}$ & 41,3 & 45,7 & 50,1 & 54,6 & 59,0 & 63,4 & 67,8 & 72,2 & 76,7 & 81,1 & 85,4 & 89,8 & 94,2 \\
\hline
\end{tabular}

$L$ - długość gazociągu [m],

$p_{1}$ - ciśnienie na początku [kPa],

$p_{2}$ - ciśnienie na końcu [kPa],

$Q_{n}$ - strumień gazu $\left[\mathrm{m}^{3} / \mathrm{h}\right]$.

$Z$ - liczba gazowa zależna od gęstości względnej gazu (tablica 1).

Wartość gęstości względnej wymaganej w powyższych wzorach została wyliczona na podstawie równania (3) z wykorzystaniem addytywności gęstości bezwzględnej gazu (4) oraz gęstości powietrza.

$$
\begin{gathered}
d=\frac{\varrho_{g}}{\varrho_{p}} \\
\varrho_{g}=\sum_{i=1}^{n} x_{i} \cdot \varrho_{i}
\end{gathered}
$$

gdzie:

$x_{i}$ - ułamek molowy [-],

$\varrho_{i}-$ gęstość $\left[\mathrm{kg} / \mathrm{m}^{3}\right]$,

$\varrho_{p}-$ gęstość powietrza $\left[\mathrm{kg} / \mathrm{m}^{3}\right]$.

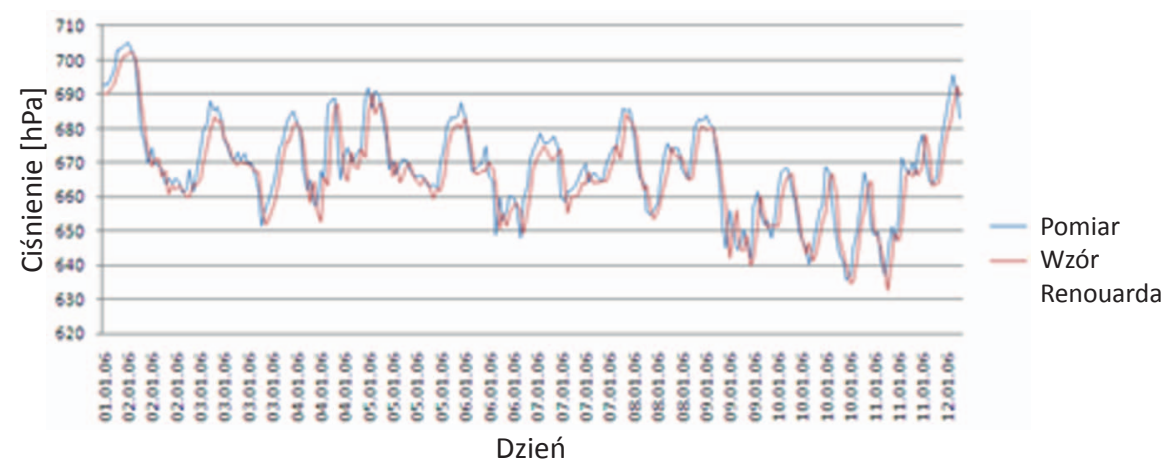

Rys. 3. Wykres przedstawiający zmiany ciśnienia zmierzonego i obliczonego według równania Renouarda

Tablica 2. Skład molowy gazu

\begin{tabular}{|l|c|c|c|}
\hline \multirow{2}{*}{ Składnik } & \multirow{2}{*}{ Symbol } & $\begin{array}{c}\text { Ułamek } \\
\text { molowy }\end{array}$ & $\begin{array}{c}\text { Gęstość } \\
\text { bezwzględna }\end{array}$ \\
\cline { 3 - 4 } & & - & $\mathrm{kg} / \mathrm{m}^{3}$ \\
\hline Metan & $\mathrm{CH}_{4}$ & 0,790 & 0,7175 \\
\hline Etan & $\mathrm{C}_{2} \mathrm{H}_{6}$ & 0,100 & 1,3552 \\
\hline Propan & $\mathrm{C}_{3} \mathrm{H}_{8}$ & 0,055 & 2,0098 \\
\hline n-butan & ${\mathrm{n}-\mathrm{C}_{4} \mathrm{H}_{10}}^{*}$ & 0,015 & 2,7090 \\
\hline i-butan & $\mathrm{i}-\mathrm{C}_{4} \mathrm{H}_{10}$ & 0,010 & 2,7068 \\
\hline n-pentan & $\mathrm{n}_{-} \mathrm{C}_{5} \mathrm{H}_{12}$ & 0,024 & 3,5065 \\
\hline Azot & $\mathrm{N}_{2}$ & 0,005 & 1,2504 \\
\hline Dwutlenek węgla & $\mathrm{CO}_{2}$ & 0,001 & 1,9767 \\
\hline
\end{tabular}

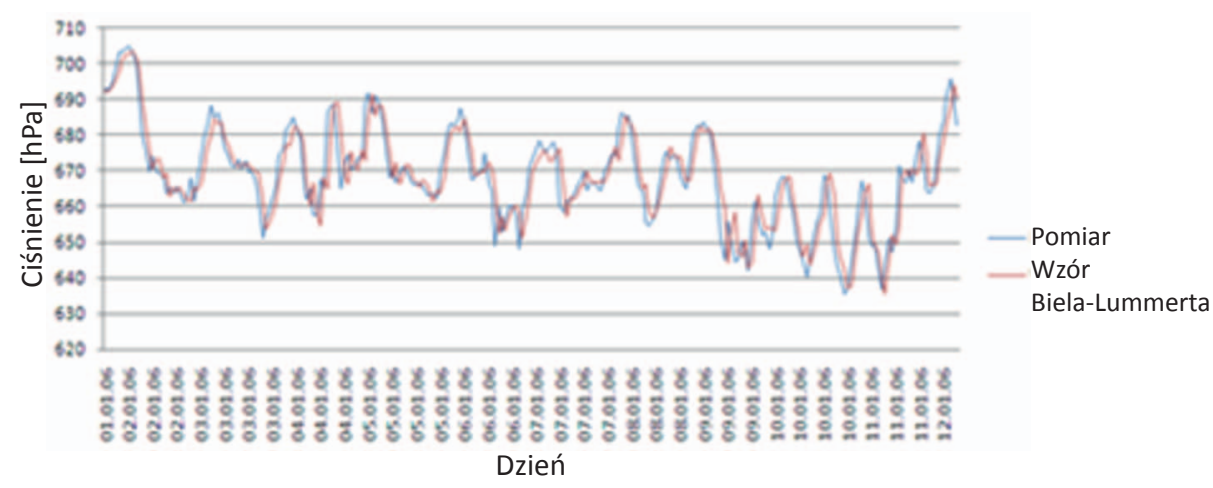

Rys. 4. Wykres przedstawiający zmiany ciśnienia zmierzonego i obliczonego według równania Biela-Lummerta

W tablicy 2 przedstawiony został skład molowy gazu, który wykorzystywany był w trakcie obliczeń. Zamieszczono również wartości gęstości bezwzględnej składników, które występują w gazie ziemnym. Dla zobrazowania dokładności wyników otrzymanych za pomocą równań przeprowadzono dwunastodniową prognozę spadku ciśnienia na bazie pomiarów uzyskanych ze stacji pomiarowej (rysunki 3, 4) [1,6].

\section{Obliczenia w programie STANET}

W programie przeprowadzono analizę odcinka (rysunek 5) dla 20 godzin pracy gazociągu. Parametry sieci oraz medium przedstawiono $\mathrm{w}$ tablicy 3 .

Na rysunku 6 przedstawiono porównanie wyników obliczeń uzyskanych z wykorzystaniem programu STANET ze zmierzonymi wartościami pomiarowymi.

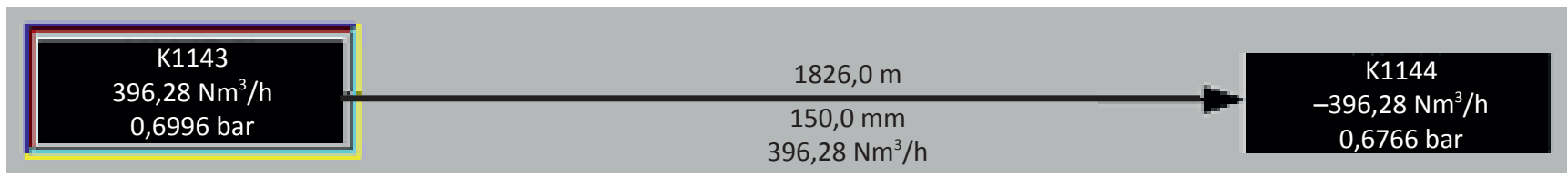

Rys. 5. Schemat badanego odcinka w programie STANET 
Tablica 3. Wartości parametrów sieci w programie STANET

\begin{tabular}{|c|c|c|}
\hline Parametr & Jednostka & Wartość \\
\hline \multicolumn{3}{|c|}{ Medium } \\
\hline Gęstość & $\mathrm{kg} \cdot \mathrm{m}^{-3}$ & 0,98 \\
\hline Lepkość & $10^{-6} \cdot \mathrm{kg} \cdot \mathrm{m}^{-1} \cdot \mathrm{s}^{-1}$ & 11,96 \\
\hline \multicolumn{3}{|c|}{ Rura } \\
\hline Chropowatość powierzchni & $\mathrm{mm}$ & 0,001 \\
\hline Średnica wewnętrzna & $\mathrm{mm}$ & 150 \\
\hline Długość & $\mathrm{m}$ & 1825 \\
\hline Długość zaworu & $\mathrm{m}$ & 1,0 \\
\hline \multicolumn{3}{|c|}{ Symulacja } \\
\hline Maksymalna liczba kroków iteracji & - & 15 \\
\hline Tolerancja przepływu przez węzeł & $\mathrm{m}^{3} \cdot \mathrm{h}^{-1}$ & 0,001 \\
\hline Tolerancja spadku ciśnienia & bar & 0,0001 \\
\hline Współczynnik liniowych strat ciśnienia & - & Prandtl-Colebrook \\
\hline
\end{tabular}

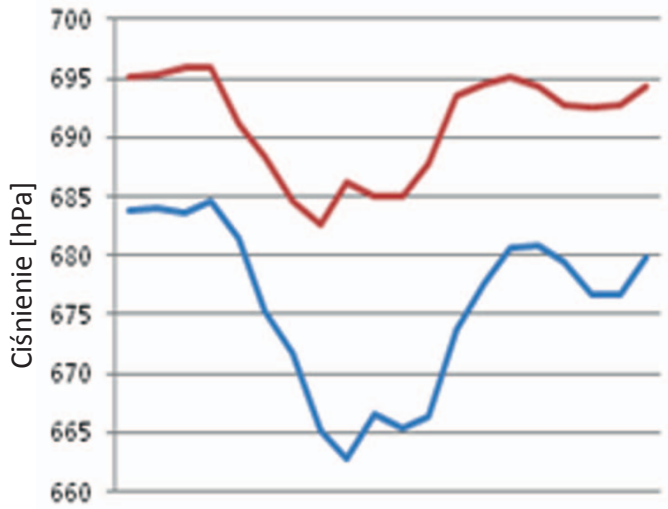

\section{0 Godziny [h] \\ —zmierzone obliczone za pomoca programu STANET}

Rys. 6. Porównanie ciśnienia zmierzonego i obliczonego w programie STANET dla 20 godzin

\section{Uczenie sieci neuronowej}

W trakcie badań wstępnych sprawdzono wpływ stopnia złożoności struktury sieci neuronowej na jakość jej uczenia. W tym celu analizowano pracę dwóch sieci o różnej liczbie warstw ukrytych oraz różnej liczbie neuronów w warstwie ukrytej. W obu sieciach neuronowych w warstwie zewnętrznej znajdowały się trzy neurony wejściowe oraz jeden w warstwie wyjściowej. Każda sieć, która była wykorzystywana do obliczeń, jest siecią jednokierunkową. Różnice w strukturze sieci polegały na budowie warstw ukrytych. Pierwsza, prostsza sieć posiadała jedną warstwę ukrytą z 25 neuronami, natomiast druga, bardziej skomplikowana, dwie warstwy ukryte z 30 neuronami w pierwszej i 20 neuronami w drugiej warstwie ukrytej. Parametry niezależne podawane na wejściu to: strumień przepływającego gazu, temperatura oraz ciśnienie początkowe. Parametr na wyjściu to ciśnienie końcowe. Schematy struktury sieci wykorzystanych do nauki przedstawione zostały na rysunkach 7 i 8 . Wyniki otrzymane po uczeniu w programie QNET zamieszczono w tablicy 4 oraz na rysunkach 9 i 10 .

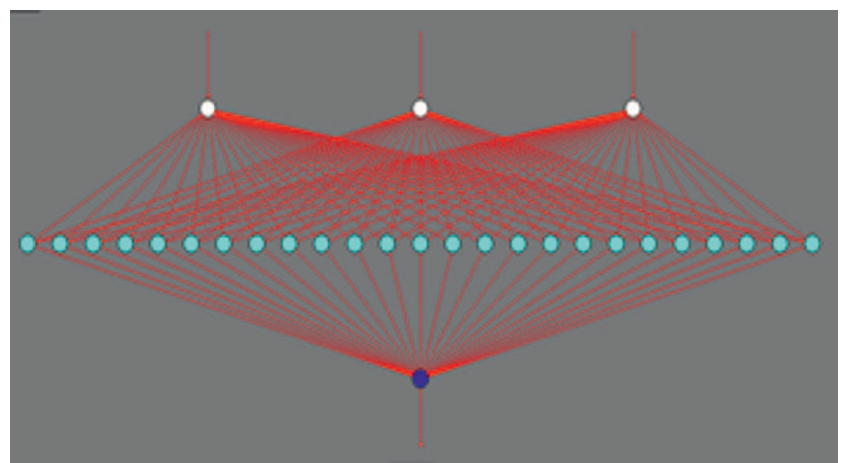

Rys. 7. Sieć jednokierunkowa z jedną warstwą ukrytą

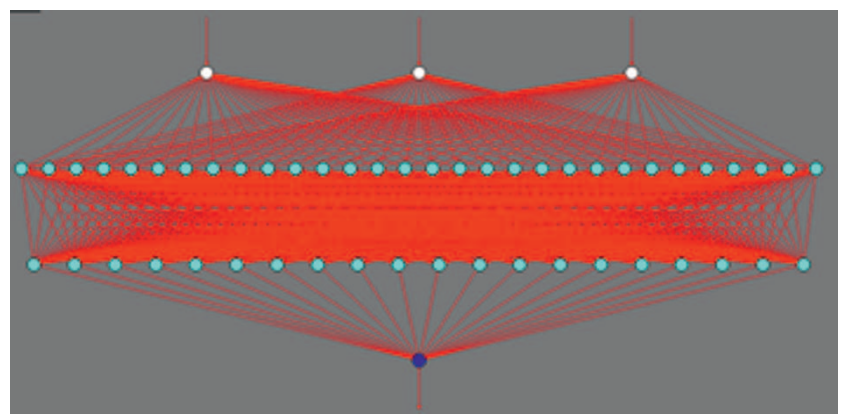

Rys. 8. Sieć jednokierunkowa z dwiema warstwami ukrytymi

Tablica 4. Wartości błędów oraz odchyleń po procesie uczenia sieci neuronowej

\begin{tabular}{|c|c|c|c|c|}
\hline $\begin{array}{c}\text { Typ sieci } \\
\text { jednokierunkowej }\end{array}$ & $\begin{array}{c}\text { Liczba } \\
\text { stopni } \\
\text { iteracji }\end{array}$ & $\begin{array}{c}\text { Stosunek standardowych } \\
\text { odchyleń błędu predykcji } \\
\text { i danych dla sieci uczonej }\end{array}$ & $\begin{array}{c}\text { Współczynnik } \\
\text { korelacji dla } \\
\text { sieci uczonej }\end{array}$ & $\begin{array}{c}\text { Standardowe } \\
\text { odchylenie } \\
\text { danych }\end{array}$ \\
\hline Jedna warstwa ukryta & 5000 & 0,04505 & 0,958 & 5,93 \\
\hline Jedna warstwa ukryta & 10000 & 0,04450 & 0,949 & 5,65 \\
\hline Dwie warstwy ukryte & 10000 & 0,04410 & 0,950 & 5,73 \\
\hline
\end{tabular}




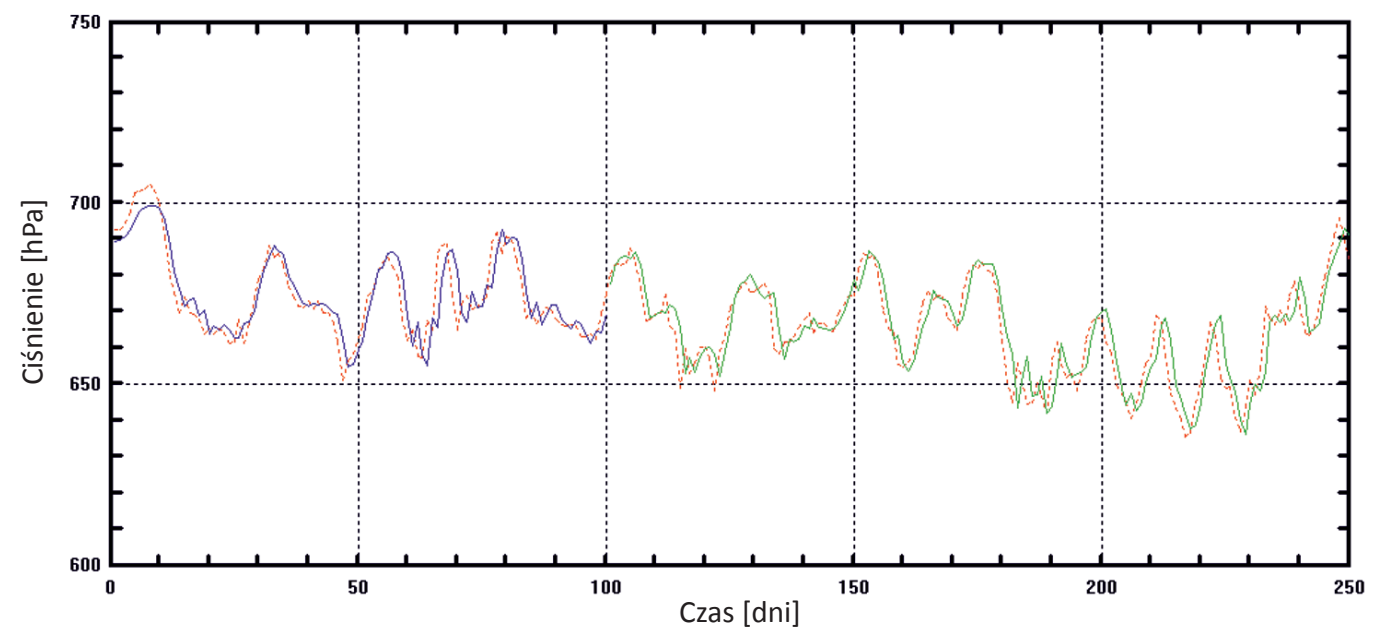

Rys. 9. Wykres przedstawiający okres uczenia sieci. Kolorem czerwonym zaznaczono dane pomiarowe, zielonym wyniki uzyskane w trakcie uczenia sieci, niebieskim wyniki uzyskane podczas testowania sieci. Sieć poddana 10000 stopni iteracji, posiada jedną warstwę ukrytą

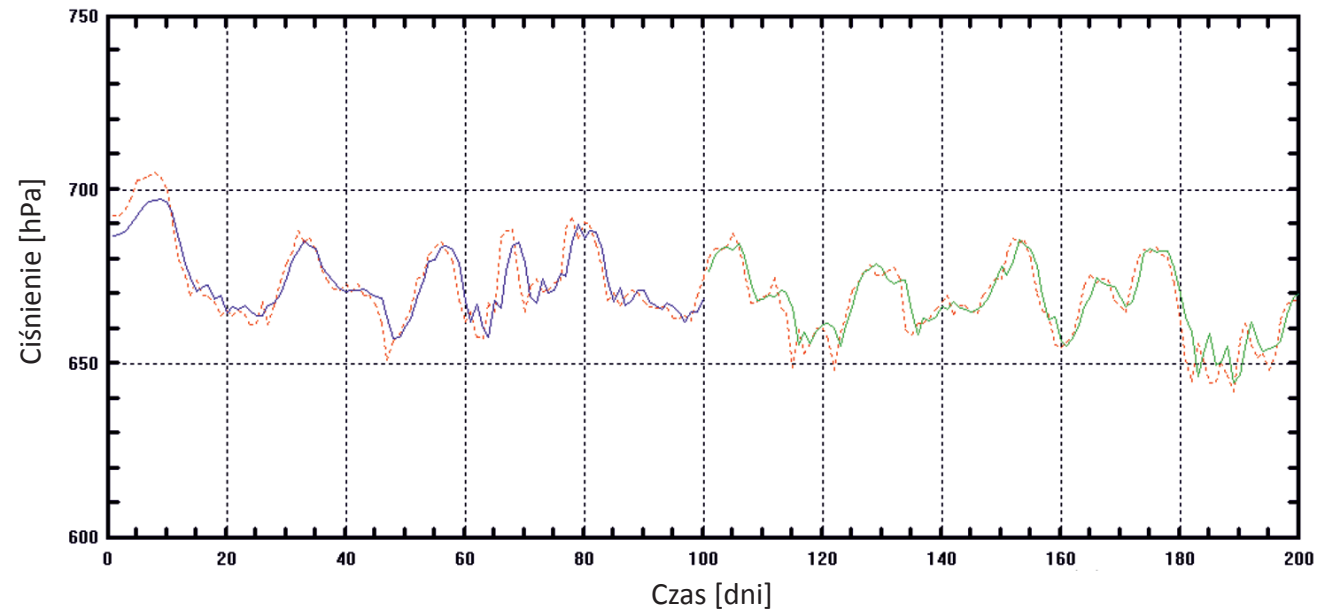

Rys. 10. Wykres przedstawiający okres uczenia sieci. Kolorem czerwonym zaznaczono dane pomiarowe, zielonym wyniki uzyskane w trakcie uczenia sieci, niebieskim wyniki uzyskane podczas testowania sieci. Sieć poddana 10000 stopni iteracji, posiada dwie warstwy ukryte

\section{Wykorzystanie nauczonej sieci neuronowej do przewidywania ciśnień}

Na podstawie przeprowadzonych obliczeń wstępnych wybrano sieć jednowarstwową z 10000 stopni iteracji, ponieważ wyniki nieznacznie różnią się od sieci bardziej skomplikowanych (rysunek 11).

W wyniku procesu uczenia wybranej struktury sieci neuronowej z 10000 stopni iteracji uzyskano następujące parametry opisujące sieć:

- odchylenie standardowe - 5,65 hPa;

- współczynnik korelacji - 0,949.

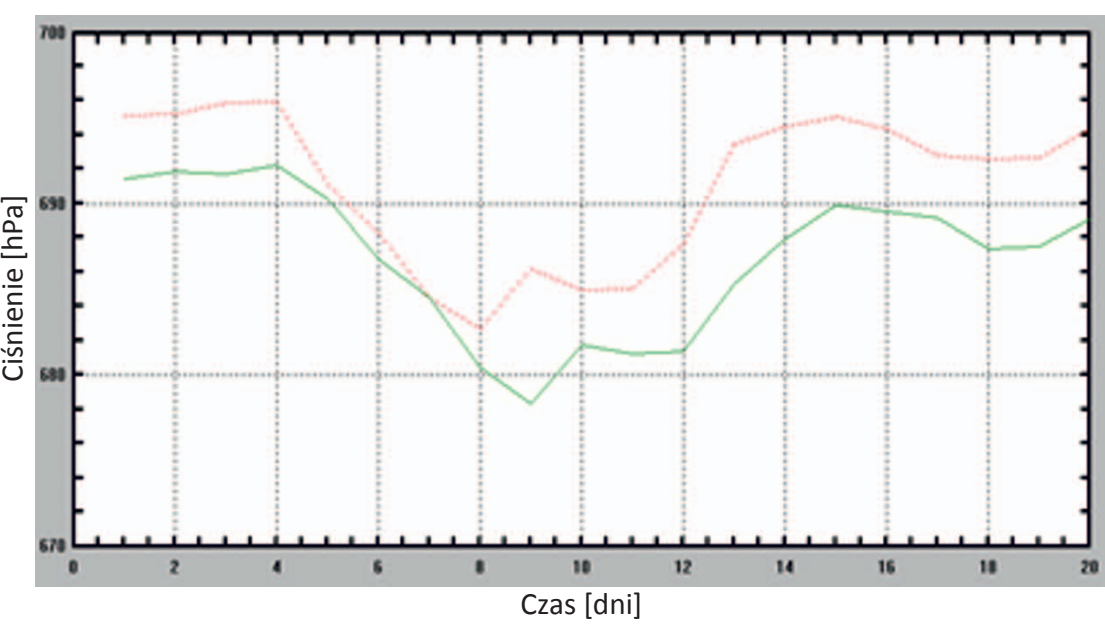

Rys. 11. Graficzne porównanie wyników pomiaru oraz analizy nauczonej sieci neuronowej. Kolorem czerwonym zaznaczono dane pomiarowe, zielonym wyniki uzyskane w trakcie uczenia sieci 


\section{Analiza wyników}

Do porównania uzyskanych wyników z rzeczywistymi wartościami ciśnienia zmierzonego na końcu odcinka gazociągu wykorzystano współczynniki korelacji Pearsona (5) oraz odchylenia standardowego (6), których wartości zostały obliczone na podstawie następujących wzorów [12]:

$$
\begin{gathered}
r=\frac{\sum_{i=1}^{n}\left(x_{i}-\bar{x}\right)-\left(y_{i}-\bar{y}\right)}{\sqrt{\sum_{i=1}^{n}\left(x_{i}-\bar{x}\right)^{2} \sum_{i=1}^{n}\left(y_{i}-\bar{y}\right)^{2}}} \\
\sigma=\sqrt{\frac{\sum_{i=1}^{n}\left(x_{i}-\mu\right)^{2}}{n}}
\end{gathered}
$$

gdzie:

$x_{i}$ - wartość $i$-tego pomiaru,

$\bar{x}$ - wartość średnia pomiarów,

$y_{i}$ - wartość $i$-tego wyniku obliczeń,

$\bar{y}$ - wartość średnia obliczeń, $\mu$ - wartość oczekiwana,

$n$ - liczba pomiarów.

W tablicy 5 przedstawione zostały uzyskane wartości współczynników dla poszczególnych metod stosowanych do określenia ciśnienia na końcu odcinka gazociągu.

Tablica 5. Wartości współczynnika korelacji i standardowego odchylenia dla wszystkich metod

\begin{tabular}{|l|c|c|}
\hline \multirow{2}{*}{\multicolumn{1}{|c}{ Nazwa metody }} & $\begin{array}{c}\text { Odchylenie } \\
\text { standardowe }\end{array}$ & $\begin{array}{c}\text { Współczynnik } \\
\text { korelacji }\end{array}$ \\
\cline { 2 - 3 } & $\mathrm{hPa}$ & - \\
\hline Wzór Renouarda & 4,160 & 0,877 \\
\hline Wzór Biela-Lummerta & 4,120 & 0,874 \\
\hline Program STANET & 9,610 & 0,847 \\
\hline Sztuczne sieci neuronowe & 4,712 & 0,881 \\
\hline
\end{tabular}

\section{Wnioski}

Należy stwierdzić, że próba przewidzenia spadku ciśnienia w sieci gazowej przy wykorzystaniu wzorów Renouarda i Biela-Lummerta oraz sieci neuronowych zakończyła się sukcesem. Najwyższy współczynnik korelacji posiadają obliczenia z zastosowaniem sztucznych sieci neuronowych, a najwyższe odchylenie standardowe wykazuje program STANET (tablica 5). W czasie prowadzenia obliczeń zauważono, że liczba warstw ukrytych oraz liczba stopni iteracji nie mają większego znaczenia dla wyniku obliczeń, lecz wpływają jedynie na czas prowadzonych symulacji.

Na wykresie (rysunek 12) można zauważyć, że najbliżej wyników pomiarów znajdują się obliczenia wykonane na podstawie wzorów Biela-Lummerta i Renouarda. Najgorzej przewidywał spadek ciśnienia program STANET. Obliczenia za pomocą nauczonej sieci neuronowej dały zadowalające wyniki - maksymalna różnica wyniosła $5 \mathrm{hPa}$ (poniżej 1\%) między zmierzonym ciśnieniem a przewidywanym.

Pomimo że wyniki otrzymane za pomocą wzorów są dokładniejsze, to sieci neuronowe są bardziej użyteczne, ponieważ można wziąć pod uwagę czynniki takie jak wiatr i nasłonecznienie, nie przeprowadzając długich i żmudnych obliczeń. Wysoki współczynnik korelacji potwierdza użyteczność techniki przewidywania zmian ciśnienia za pomocą sztucznych sieci neuronowych.

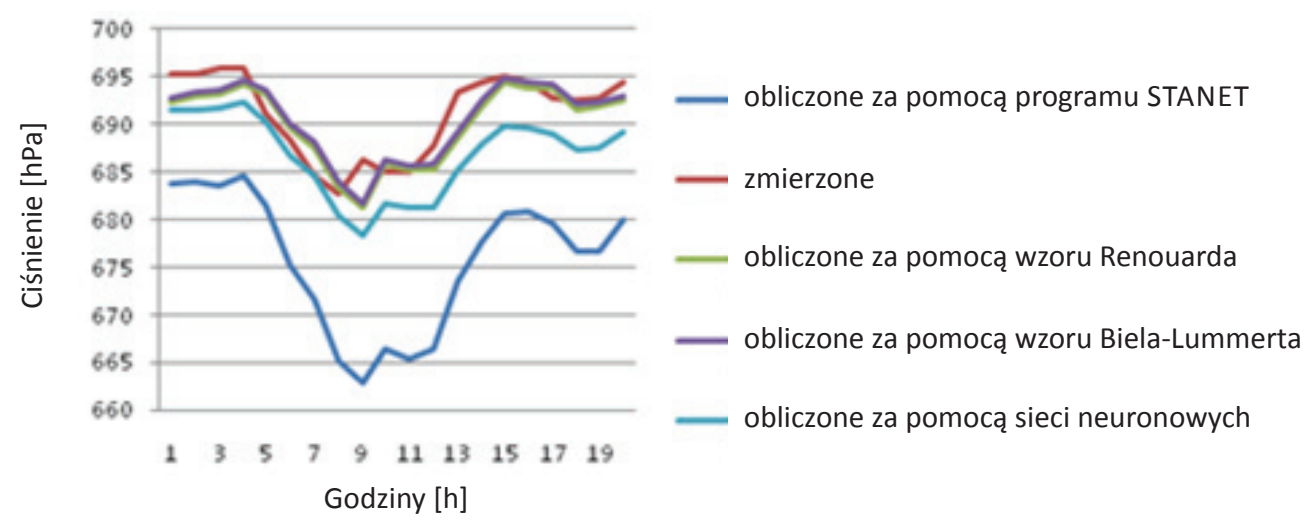

Rys. 12. Zestawienie wszystkich wyników obliczeń prowadzonych w celu przewidzenia spadku ciśnienia 
Artykuł powstał na podstawie referatu zaprezentowanego na Konferencji Naukowo-Technicznej FORGAZ 2016 „Techniki i technologie dla gazownictwa - pomiary, badania, eksploatacja”, zorganizowanej przez INiG - PIB w dniach 13-15 stycznia 2016 r.

w Muszynie.

\section{Literatura}

[1] Bąkowski K.: Sieci i instalacje gazowe. Warszawa, Wydawnictwo Naukowo-Techniczne, 2007.

[2] Chmielnicki W.: Algorytmy wykorzystujace sieci neuronowe do regulacji węzłów ciepłowniczych. Rynek Energii 2010, nr 6, s. 62-70.

[3] Kelner M.: Prognozowanie krótkoterminowe poborów gazu z sieci przemystowej metoda sztucznych sieci neuronowych. Gaz, Woda i Technika Sanitarna 2003, nr 6, s. 196-204.

[4] Klaus R.: Sztuczne sieci neuronowe. http://www.cs.put.poznan.pl/rklaus/assn/neuron.htm (dostęp: 11.04.2016).

[5] Kogut K.: Analiza możliwości modelowania sieci przesyłowej gazu ziemnego. Kraków, Wydawnictwa AGH, 2007.

[6] Kogut K.: Obliczanie sieci gazowych. Kraków, Uczelniane Wydawnictwo Naukowo-Dydaktyczne AGH, 2007.

[7] Maciejasz M.: Zastosowanie sieci neuronowych do analizy pracy sieci przesyłowych. Kraków, Wydawnictwa AGH, 2006.

[8] Madziuk J.: Sieci neuronowe typu Hopfielda. Teoria i przykłady zastosowań. Warszawa, Akademicka Oficyna Wydawnicza, 2000.

[9] Mazur M., Sobczak B.: Zachowanie sie farm wiatrowych $w$ warunkach zagrożenia blackoutem. Instytut Energetyki, Jednostka Badawczo-Rozwojowa, Gdańsk.

[10] Osman E. A.: Prediction of Oil PVT Properties Using Neural Network. SPE 68223, marzec 2001.

[11] Rymarczyk M. (red.): Decyzje, symulacje, sieci neuronowe.

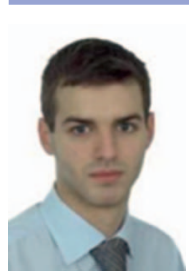

Mgr inż. Tomasz CIEŚLIK

Doktorant na Wydziale Wiertnictwa Nafty i Gazu

Akademia Górniczo-Hutnicza

Katedra Inżynierii Gazowniczej

al. Adama Mickiewicza 30, 30-059 Kraków

E-mail:tcieslik@agh.edu.pl

Pracownik IFJ PAN w Krakowie
Poznań, Wydawnictwo Wyższej Szkoły Bankowej w Poznaniu, 1997.

[12] Statystyka - zadania z rozwiązaniami. http://www.statystyka-zadania.pl/wspolczynnik-korelacji-liniowej-pearsona/ (dostęp: 11.04.2016).

[13] Stefanowski J., Krawiec K.: Wykłady z sieci neuronowych Instytut Informatyki Politechniki Poznańskiej, 1995.

[14] Strzoda J., Skrzypiec M.: Czy jesteśmy przygotowani na blackout? „Koncern”, Luty 2007, http://www.cire.pl/pliki/2/przygotblackout.pdf (dostęp: 11.04.2016).

[15] Sztuczne sieci neuronowe i algorytmy genetyczne. http://4programmers.net/Z_pogranicza/Sztuczne_sieci_neuronowe_i_algorytmy genetyczne\#r12 (dostęp: 11.04.2016).

[16] Tadeusiewicz R.: Elementarne wprowadzenie do technik sieci neuronowych z przyktadowymi programami. Warszawa, Akademicka Oficyna Wydawnicza PLJ, 1998.

[17] Tadeusiewicz R.: Sieci neuronowe. Warszawa, Akademicka Oficyna Wydawnicza RM, 1993.

[18] Tadeusiewicz R., Gąciarz T., Borowik B., Leper B.: Odkrywanie właściwości sieci neuronowych przy użyciu programów w języku C\#. Polska Akademia Umiejętności, Międzywydziałowa Komisja Nauk Technicznych, 2007.

[19] Wójcik M.: Model sieci gazowniczej oparty o sztuczne sieci neuronowe. Kraków, Wydawnictwo AGH, 2005.

[20] Żurada J., Barski M., Jędruch W.: Sztuczne sieci neuronowe. Warszawa, Wydawnictwo Naukowe PWN, 1996.

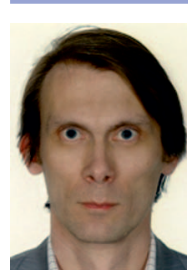

Dr inż. Krzysztof KOGUT

Adiunkt na Wydziale Energetyki i Paliw

Akademia Górniczo-Hutnicza

Katedra Technologii Paliw

al. Adama Mickiewicza 30

30-059 Kraków

E-mail:kogut@agh.edu.pl 